\title{
Margaret McCartney: Female genital mutilation: a wise doctor and a foolish prosecution
}

\author{
Margaret McCartney general practitioner, Glasgow
}

Wisdom is recognisable for its facets of fair judgment, experience, carefulness, and compassion-but also a degree of risk taking. The wise people I know make choices that are based on likely consequences. They consider all options but are also decisive. They are fair minded, having little ego to get in the way of what might be best for others. Wise people make good role models, although they most likely hate this. Shakespeare had it right: "The fool doth think he is wise, but the wise man knows himself to be a fool."

The risk taking is important; wise people are not interested in "covering their backs." The jury judging Dhanuson Dharmasena rapidly acquitted him as innocent against charges that he had committed female genital mutilation (FGM) in 2012 at a London hospital. His patient, whom he saw as an emergency in labour, had been subjected to FGM previously in Somalia. To deliver the child, Dharmasena had to make an incision, but it continued to bleed. To stop this he inserted one single suture and was called away to another emergency immediately. ${ }^{1} \mathrm{He}$ was concerned about what he had done, though, in case it infringed the Female Genital Mutilation Act 2003. This act states, however, that "no offence is committed by an approved person who performs ... a surgical operation on a girl who is in any stage of labour, or has just given birth, for purposes connected with the labour or birth."2

Dharmasena was concerned that the stitch reconstituted the patient's FGM, and-as reflective, thoughtful doctors should do-he sought advice. The hospital held a "serious untoward incident" review, which should have realised that the patient should have been recognised as having had FGM well before she went into labour, allowing plans to be made before an emergency arose. The hospital referred the matter to the police, who contacted the Crown Prosecution Service (CPS), which decided to press charges against the doctor-the first such UK action.

But this was not a doctor intending FGM — rather, one dealing with an emergency situation and one who, wisely, had doubted his own actions and sought advice; if only a wise person in the CPS had realised that bringing the matter to court was a mistake. A far bigger issue is that girls are being taken abroad from the United Kingdom to have their genitals cut - not only with the consent, but also by the organisation, of the people who are meant to care for them. ${ }^{3}$ Why has the CPS yet to bring any prosecutions for that?

Competing interests: I have read and understood the BMJ policy on declaration of interests and declare the following interests: I'm an NHS GP partner, with income partly dependent on Quality and Outcomes Framework points. I'm a part time undergraduate tutor at the University of Glasgow. I've written two books and earn from broadcast and written freelance journalism. I'm an unpaid patron of Healthwatch. I make a monthly donation to Keep Our NHS Public. I'm a member of Medact. I'm occasionally paid for time, travel, and accommodation to give talks or have locum fees paid to allow me to give talks but never for any drug or public relations company. I was elected to the national council of the Royal College of General Practitioners in 2013 and am chair of its standing group on overdiagnosis. I have invested a small amount of money in a social enterprise, Who Made Your Pants?

The BMS's readers can buy Margaret's new book, Living with Dying, for $£ 7.99$ (RRP £11.99) including UK delivery from www.pinterandmartin. com with checkout code BMJ799.

Provenance and peer review: Commissioned; not externally peer reviewed.

Follow Margaret on Twitter, @mgtmccartney

1 Laville S. First FGM prosecution: how the case came to court. Guardian 4 February 2014 www.theguardian.com/society/2015/feb/04/first-female-genital-mutilation-prosecutiondhanuson-dharmasena-fgm.

2 UK Government. Female Genital Mutilation Act 2003. www.legislation.gov.uk/ukpga/2003/ $31 /$ section/1.

3 UK Government. Female genital mutilation: the facts. www.gov.uk/government/uploads/ system/uploads/attachment_data/file/300167/FGM_leaflet_v4.pdf. 